\title{
Review: Komposisi Vegetasi dan Keragaman Gulma di Lahan Padi Sawah
}

\author{
Kartika Yurlisa ${ }^{*}$ \\ ${ }^{1}$ Jurusan Budidaya Pertanian, Fakultas Pertanian, Universitas Brawijaya \\ *Corresponding author: kartikayurlisa2@gmail.com
}

\begin{abstract}
Abstrak
Padi (Oryza sativa L.) merupakan makanan pokok penduduk di Indonesia, dan berperan penting pada stabilitas ekonomi dan sosial. Gulma ialah tumbuhan yang mengganggu pertumbuhan tanaman budidaya. Gulma termasuk salah satu penyebab penurunan produktivitas padi. Keberadaan gulma selain memberikan dampak negatif, juga mempunyai manfaat yang positif pada lingkungan. Saat ini, jumlah gulma telah menurun drastis di lanskap pertanian karena perubahan lingkungan dan aktivitas manusia. Penelitian ini dilakukan dengan tujuan untuk menginventarisasi dan mengklasifikasikan keanekaragaman gulma pada tanaman padi di Indonesia. Artikel ini ditulis berdasarkan kajian literatur hasil penelitian selama 8 tahun dari tahun 2012 sampai dengan 2020 pada delapan lokasi di lahan sawah Indonesia yang berbeda. Komposisi vegetasi dan keragaman gulma telah dikaji dengan seksama. Dari hasil penelusuran pustaka didapatkan 59 spesies gulma di lahan padi sawah. Spesies-spesies ini terdistribusikan pada 42 genus dan 21 famili.
\end{abstract}

Kata kunci: Gulma, Indonesia, Keanekaragaman, Padi sawah

\begin{abstract}
Rice (Oryza sativa L.) is the staple food in Indonesia and plays an important economic and social role. Weeds are plants that interfere with the growth of crops. Weeds are one of the causes that decreased rice productivity. The presence of weeds besides having negative impacts also has positive benefitss on the environment. Today, the number of weeds has decreased drastically in the agricultural landscape due to environmental changes and human activities. This research was conducted with the aim of inventory and classify the diversity of weeds in Indonesian rice fields. This article is based on the literature review of research from 8 years from 2012 to 2020 in eight different locations of Indonesian rice fields. Vegetation composition and weed diversity have been carefully assessed. From the results of the literature search, it finds that 59 species of weeds in lowland rice fields. These species are distributed in 42 genera and 21 families.
\end{abstract}

Keywords: Diversity, Indonesia, Lowland rice, Weeds 
Prosiding Seminar Nasional Pembangunan dan Pendidikan Vokasi Pertanian

Politeknik Pembangunan Pertanian Manokwari, 31 Juli 2021

e ISSN : 2774-1982

DOI : https://doi.org/10.47687/snppvp.v2i1.198

\section{PENDAHULUAN}

Padi merupakan makanan pokok penduduk di Indonesia, dan berperan penting dalam stabilitas ekonomi dan sosial di Indonesia. Jumlah penduduk Indonesia yang mencapai 270,20 juta orang dengan produksi beras pada tahun 2020 mencapai 31,33 juta ton (BPS, 2020; BPS, 2021).

Gulma merupakan salah satu dari Organisme Pengganggu Tanaman (OPT) yang menghambat pertumbuhan, perkembangan dan produktivitas tanaman (Palijama et al., 2018). Kehilangan hasil yang tertinggi yang disebabkan oleh gulma pada budidaya padi varietas Ciherang yaitu sebesar 30,1\% didapatkan pada perlakuan budidaya padi dengan jarak tanam $30 \mathrm{~cm}$ x $30 \mathrm{~cm}$ dengan tanpa penyiangan (Widayat dan Purba, 2015). Gulma yang tumbuh subur bersama dengan tanaman padi menurunkan produksi pertanian. Keberadaan gulma selain memberikan dampak negatif, gulma juga dapat memberikan manfaat yang positif. Bunga gulma dapat memberikan pakan alternatif dan sebagai tempat berlindung bagi serangga. Mayoritas serangga predator dan parasitoid mendapatkan keuntungan dari gulma. Bastiaans et al. (2000) menyimpulkan bahwa gulma membentuk dasar dari jaring makanan di agroekosistem. Saat ini, jumlah spesies gulma telah menurun drastis di lanskap pertanian karena perubahan lingkungan dan aktivitas manusia (Hyvönen, 2007; Fried et al., 2009).

Komposisi vegetasi dan keragaman gulma dapat berbeda beda tergantung pada lokasi, suplai air, praktik budaya, vegetasi gulma yang melekat di daerah tersebut, dan tanaman yang ditanam. Informasi mengenai variasi spasial gulma berperan penting dalam meningkatkan efisiensi metode pengelolaan gulma. Memahami struktur sosiologis gulma di sawah merupakan prasyarat untuk pengelolaan yang efektif. Pengelolaan gulma dapat menjadi langkah yang efektif dalam meningkatkan produksi dan dalam menjaga potensi hasil tanaman yang sebenarnya kemudian meningkatkan produktivitas. Oleh karena itu, review ini dilakukan dengan tujuan untuk menginventarisasi dan mengklasifikasikan keanekaragaman gulma pada tanaman padi di Indonesia melalui kajian literatur hasil penelitian selama 8 tahun dari tahun 2012 sampai dengan 2020.

\section{METODE}

Pencarian sistematis literatur yang relevan telah dilakukan dengan menggunakan mesin pencarian google (hasil penelitian tersedia secara online). Pencarian dilakukan pada bulan Juli 2021, menggunakan beberapa kata kunci sebagai berikut: penelitian, gulma dan padi. Batasan geografi ditetapkan yaitu penelitian yang berada di negara 
Prosiding Seminar Nasional Pembangunan dan Pendidikan Vokasi Pertanian

Politeknik Pembangunan Pertanian Manokwari, 31 Juli 2021

e ISSN : 2774-1982

DOI : https://doi.org/10.47687/snppvp.v2i1.198

Indonesia. Dan tidak ada batasan bahasa yang diterapkan pada proses penyaringan.

Pencarian ini menghasilkan 30 artikel, yang judul dan abstraknya disaring untuk kelayakan. Artikel disaring dengan menggunakan pedoman berdasarkan kriteria sebagai berikut: (a) artikel diterbitkan dalam jurnal/prosiding yang mengalami proses penelaahan, (b) artikel berdasarkan studi yang dilakukan dengan desain eksperimental terstruktur, (c) artikel melaporkan satu atau tiga variabel sebagai berikut: identifikasi, nama latin, famili, dan golongan gulma. Proses ini menghasilkan 8 artikel penelitian lengkap yang menjadi basis data penulisan. Daftar lengkap publikasi artikel penelitian yang digunakan disajikan pada Tabel 1.

Tabel 1. Pustaka hasil penelitian yang menjadi acuan review

\begin{tabular}{|c|c|c|c|c|c|c|c|c|}
\hline Sumber & $\begin{array}{l}\text { Utami dan } \\
\text { Purdyaningr } \\
\text { um, } 2012\end{array}$ & $\begin{array}{c}\text { Fitri et } \\
\text { al., } 2014\end{array}$ & $\begin{array}{c}\text { Rosanti, } \\
2016\end{array}$ & $\begin{array}{c}\text { Farmanta } \\
\text { dan } \\
\text { Rosmanah, } \\
2016 \\
\end{array}$ & $\begin{array}{l}\text { Irwansyah } \\
\text { et al., } \\
2017\end{array}$ & $\begin{array}{c}\text { Syarifah } \\
\text { et al., } \\
2018\end{array}$ & $\begin{array}{l}\text { Kurniadie } \\
\text { et al., } \\
2018\end{array}$ & $\begin{array}{c}\text { Syaifudin } \\
\text { dan Nofa, } \\
2020\end{array}$ \\
\hline Jenis padi & \multicolumn{8}{|c|}{ Padi sawah } \\
\hline $\begin{array}{l}\text { Lokasi } \\
\text { penelitian }\end{array}$ & $\begin{array}{c}\text { Ketapan, } \\
\text { Susukan, } \\
\text { Semarang, } \\
\text { Prov. Jawa } \\
\text { Tengah }\end{array}$ & $\begin{array}{c}\text { Nagari } \\
\text { Singkara } \\
\text { k, Solok, } \\
\text { Prov. } \\
\text { Sumater } \\
\text { a Barat }\end{array}$ & $\begin{array}{c}\text { Jakabari } \\
\text { ng, } \\
\text { Palemba } \\
\text { ng, Prov. } \\
\text { Sumatera } \\
\text { Selatan }\end{array}$ & $\begin{array}{c}\text { Rejang } \\
\text { lebong, } \\
\text { Prov. } \\
\text { Bengkulu }\end{array}$ & $\begin{array}{c}\text { Gampong } \\
\text { Lhok } \\
\text { Iboh, } \\
\text { Baktiya } \\
\text { Barat, } \\
\text { Prov. } \\
\text { Aceh }\end{array}$ & $\begin{array}{l}\text { Rimau, } \\
\text { Banyuasi } \\
\text { n, Prov. } \\
\text { Sumatera } \\
\text { Selatan }\end{array}$ & $\begin{array}{c}\text { Pesawaha } \\
\text { n dan P. } \\
\text { salam, } \\
\text { Kab. } \\
\text { Purwakar } \\
\text { ta, Prov. } \\
\text { Jawa } \\
\text { Tengah }\end{array}$ & $\begin{array}{c}\text { Desa } \\
\text { Terban, } \\
\text { Batang, } \\
\text { Prov. Jawa } \\
\text { Tengah }\end{array}$ \\
\hline $\begin{array}{l}\text { Waktu } \\
\text { penelitian }\end{array}$ & $\begin{array}{c}\text { Desember } \\
2012\end{array}$ & $\begin{array}{c}\text { Juni- } \\
\text { Septemb } \\
\text { er } 2013\end{array}$ & $\begin{array}{c}\text { Oktober } \\
2015\end{array}$ & $\begin{array}{l}\text { Desember- } \\
\text { Februari } \\
2016\end{array}$ & $\begin{array}{c}\text { Maret- } \\
\text { Juni } 2017\end{array}$ & $\begin{array}{l}\text { Juni } \\
2017\end{array}$ & $\begin{array}{l}\text { Desember } \\
2017- \\
\text { Februari } \\
2018\end{array}$ & $\begin{array}{c}\text { Agustus } \\
2020\end{array}$ \\
\hline $\begin{array}{l}\text { Pustaka } \\
\text { ke- }\end{array}$ & 1 & 2 & 3 & 4 & 5 & 6 & 7 & 8 \\
\hline
\end{tabular}

Tabel 1 memberikan informasi bahwa jenis padi yang dijadikan komoditas penelitian adalah padi sawah, tanpa menyebutkan varietas padi yang spesifik. Lokasi penelitian berkisar dari Jawa Tengah, Sumatera Barat, Sumatera Selatan, Bengkulu, dan Aceh. Waktu penelitian selama 8 tahun dari Bulan Desember 2012 sampai dengan Agustus 2020. Fokus penulisan disini adalah keanekaragaman spesies dari gulma, bukan kepadatannya maupun total biomassanya. Dari data-data hasil penelitian tersebut disusunlah keanekaragaman spesies gulma secara sistematis dan disajikan dalam bentuk tabel terstruktur. Famili dan golongan gulma juga dikelompokkan dengan menggunakan software excell, kemudian diolah dan disajikan dalam bentuk gambar grafik. Tujuan penulisan artikel ini yaitu untuk menginventarisasi dan mengklasifikasikan keanekaragaman gulma pada tanaman padi di Indonesia melalui kajian literatur hasil penelitian selama 8 tahun dari tahun 2012 sampai dengan 2020. 
Prosiding Seminar Nasional Pembangunan dan Pendidikan Vokasi Pertanian

Politeknik Pembangunan Pertanian Manokwari, 31 Juli 2021

e ISSN : 2774-1982

DOI : https://doi.org/10.47687/snppvp.v2i1.198

\section{HASIL DAN PEMBAHASAN}

Komposisi vegetasi dan keragaman gulma pada delapan lahan sawah yang berbeda di Indonesia telah dipelajari dari bulan Desember 2012 hingga Agustus 2020. Dari hasil penelusuran pustaka didapatkan 59 spesies gulma di lahan padi sawah. Spesies-spesies ini terdistribusikan di 42 genus dan 21 famili. 57 spesies termasuk angiospermae dan 2 spesies termasuk ke dalam pteriodphyta. Dari 57 spesies angiospermae terbagi lagi menjadi 25 spesies dikotil dan 32 spesies monokotil. Jumlah spesies yang ditemukan per lokasi beragam dari 10-15 spesies. 12 spesies ditemukan di Susukan, Semarang; 10 spesies di Singkarak, Solok; 12 spesies di Jakabaring, Palembang, 10 spesies di Rejanglebong; 9 spesies di Baktiya Barat; 15 spesies di Banyuasin; 11 spesies di Purwakarta; dan 10 spesies di Batang. Dalam sudut pandang keanekaragaman gulma, lahan sawah di Banyuasin, Sumatera Selatan lebih beragam dalam keanekaragaman spesies gulma jika dibandingkan dengan lahan sawah yang lain. Distribusi spesies gulma padi sawah di Indonesia yang dilaporkan pada beberapa jurnal penelitian dari tahun 20122020 disajikan pada Tabel 2.

Tabel 2. Distribusi spesies gulma di lahan padi sawah Indonesia yang dilaporkan pada beberapa jurnal penelitian dari tahun 2012-2020

\begin{tabular}{|c|c|c|c|c|c|c|c|c|c|c|c|}
\hline \multirow{4}{*}{ No. } & \multirow{4}{*}{ Spesies } & \multirow{4}{*}{ Famili } & \multicolumn{8}{|c|}{ Pustaka ke- } & \multirow{4}{*}{ 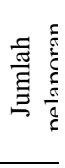 } \\
\hline & & & 1 & 2 & 3 & 4 & 5 & 6 & 7 & 8 & \\
\hline & & & 20 & 20 & 20 & 20 & 20 & 20 & $2017-$ & 20 & \\
\hline & & & 12 & 13 & 15 & 16 & 17 & 17 & 2018 & 20 & \\
\hline 1 & Acalypha indica & Euphorbiaceae & & & $*$ & & & & & & 1 \\
\hline 2 & Ageratum conyzoides L. & Asteraceae & & & $*$ & & $*$ & $*$ & & & 3 \\
\hline 3 & $\begin{array}{l}\text { Alternanthera caracasana } \\
\text { Kunth. }\end{array}$ & Amaranthaceae & & & & & & & & $*$ & 1 \\
\hline 4 & Alternanthera sessilis & Amaranthaceae & $*$ & & & & & & & & 1 \\
\hline 5 & Alternathera philoxeroides & Amaranthaceae & & & & & & & $*$ & & 1 \\
\hline 6 & $\begin{array}{l}\text { Anthoxanthum odoratum } \\
\text { L. }\end{array}$ & Graminae & & & & & & & & $*$ & 1 \\
\hline 7 & Bacopa monnieri & Plantaginaceae & & & & & & & $*$ & & 1 \\
\hline 8 & Blyxa echinosperma & $\begin{array}{l}\text { Hydrocharitacea } \\
\text { e }\end{array}$ & & & $*$ & & & & & & 1 \\
\hline 9 & Cleome rutidisprema DC. & Capparideceae & & & & & & $*$ & & & 1 \\
\hline 10 & Commelina diffusa & Commelinaceae & $*$ & & & & & & & & 1 \\
\hline 11 & $\begin{array}{l}\text { Crassocephalum } \\
\text { crepidioides }\end{array}$ & Asteraceae & & & $*$ & & & $*$ & & & 2 \\
\hline 12 & $\begin{array}{l}\text { Cynodon dactylon (L.) } \\
\text { Pers. }\end{array}$ & Graminae & $*$ & & & & $*$ & $*$ & $*$ & & 4 \\
\hline 13 & Cyperus compressus & Cyperaceae & & & $*$ & & & $*$ & & & 2 \\
\hline
\end{tabular}


Prosiding Seminar Nasional Pembangunan dan Pendidikan Vokasi Pertanian Politeknik Pembangunan Pertanian Manokwari, 31 Juli 2021

e ISSN : 2774-1982

DOI : https://doi.org/10.47687/snppvp.v2i1.198

\begin{tabular}{|c|c|c|c|c|c|c|c|c|c|c|c|}
\hline \multirow{4}{*}{ No. } & \multirow{4}{*}{ Spesies } & \multirow{4}{*}{ Famili } & \multicolumn{8}{|c|}{ Pustaka ke- } & \multirow{4}{*}{ 蛋 } \\
\hline & & & 1 & 2 & 3 & 4 & 5 & 6 & 7 & 8 & \\
\hline & & & 20 & 20 & 20 & 20 & 20 & 20 & 2017- & 20 & \\
\hline & & & 12 & 13 & 15 & 16 & 17 & 17 & 2018 & 20 & \\
\hline 14 & Cyperus difformis L. & Cyperaceae & & $*$ & & & & & & & 1 \\
\hline 15 & Cyperus iria L. & Cyperaceae & & $*$ & & & & & & & 1 \\
\hline 16 & Cyperus killingia & Cyperaceae & & & & $*$ & & & & & 1 \\
\hline 17 & Cyperus pilosus & Cyperaceae & & & $*$ & & & & & & 1 \\
\hline 18 & Cyperus rotundus & Cyperaceae & & & & $*$ & $*$ & $*$ & & & 3 \\
\hline 19 & Dactyloctenium aegyptium & Graminae & $*$ & & & & & & & & 1 \\
\hline 20 & $\begin{array}{l}\text { Digitaria adscendens sin. } \\
\text { Digitaria ciliaris (Retz.) } \\
\text { Koel }\end{array}$ & Graminae & & & & $*$ & & $*$ & $*$ & & 3 \\
\hline 21 & Digittaria longiflora & Graminae & & & $*$ & & & & & & 1 \\
\hline 22 & Drymaria cordata & $\begin{array}{l}\text { Caryophyllacea } \\
\text { e }\end{array}$ & & & & $*$ & & & & & 1 \\
\hline 23 & Echinochloa colona & Graminae & & $*$ & & $*$ & & $*$ & & & 3 \\
\hline 24 & $\begin{array}{l}\text { Echinochloa crus-galli (L.) } \\
\text { Beauv }\end{array}$ & Graminae & & $*$ & & & $*$ & & & & 2 \\
\hline 25 & $\begin{array}{l}\text { Eclipta alba } \sin . \text { Eclipta } \\
\text { prostrata }(\mathrm{L} .)\end{array}$ & Asteraceae & $*$ & $*$ & & & & & & & 2 \\
\hline 26 & $\begin{array}{l}\text { Eichhornia crassipes (Mart.) } \\
\text { Solms }\end{array}$ & Pontederiaceae & $*$ & & & $*$ & & & & & 2 \\
\hline 27 & Eleocharis acicularis & Cyperaceae & $*$ & & & & & & & & 1 \\
\hline 28 & Eleocharis palustris L. & Cyperaceae & & & & & & $*$ & & & 1 \\
\hline 29 & Eleusin indica (L.) Gaertn. & Graminae & & & & & & $*$ & & & 1 \\
\hline 30 & Eragrostis atrovirens & Graminae & & & & $*$ & & & & & 1 \\
\hline 31 & Euphorbia hirta & Euphorbiaceae & & & $*$ & & & $*$ & & & 2 \\
\hline 32 & Fimbristylis miliacae & Cyperaceae & & $*$ & & & & $*$ & $*$ & $*$ & 4 \\
\hline 33 & $\begin{array}{l}\text { Hedyotis corymbosa (L.) } \\
\text { Lam. }\end{array}$ & Rubiaceae & & & & $*$ & & & & & 1 \\
\hline 34 & Hedyotis diffusa Willd & Rubiaceae & & $*$ & & & & & & & 1 \\
\hline 35 & Ipomoea aquatica & Convolvulaceae & & & $*$ & & & & & $*$ & 2 \\
\hline 36 & $\begin{array}{l}\text { Ipomoea obscura (L.) Ker } \\
\text { Gawl }\end{array}$ & Convolvulaceae & & & & & & & & $*$ & 1 \\
\hline 37 & Ischaemum timorense & Cyperaceae & & & $*$ & & & & & & 1 \\
\hline 38 & $\begin{array}{l}\text { Leptochloa chinensis (L.) } \\
\text { Nees }\end{array}$ & Graminae & & $*$ & & & & & $*$ & & 2 \\
\hline 39 & Lersia hexandra & Graminae & & & & & & & $*$ & & 1 \\
\hline 40 & Limnocharis flava & Alismataceae & & & & & $*$ & & & & 1 \\
\hline 41 & $\begin{array}{l}\text { Lindernia ciliata (Colsm.) } \\
\text { Pennell }\end{array}$ & Linderniaceae & & $*$ & & & & & & & 1 \\
\hline 42 & Ludwigia adscendens & Onagraceae & $*$ & & & & & & & & 1 \\
\hline
\end{tabular}


Prosiding Seminar Nasional Pembangunan dan Pendidikan Vokasi Pertanian Politeknik Pembangunan Pertanian Manokwari, 31 Juli 2021

e ISSN : 2774-1982

DOI : https://doi.org/10.47687/snppvp.v2i1.198

\begin{tabular}{|c|c|c|c|c|c|c|c|c|c|c|c|}
\hline \multirow{4}{*}{ No. } & \multirow{4}{*}{ Spesies } & \multirow{4}{*}{ Famili } & \multicolumn{8}{|c|}{ Pustaka ke- } & \multirow{4}{*}{ 丞 } \\
\hline & & & 1 & 2 & 3 & 4 & 5 & 6 & 7 & 8 & \\
\hline & & & 20 & 20 & 20 & 20 & 20 & 20 & $2017-$ & 20 & \\
\hline & & & 12 & 13 & 15 & 16 & 17 & 17 & 2018 & 20 & \\
\hline 43 & $\begin{array}{l}\text { Ludwigia hyssopifolia (G. } \\
\text { Don) Exell }\end{array}$ & Onagraceae & & $*$ & & & & & & & 1 \\
\hline 44 & Ludwigia octovalvis & Onagraceae & $*$ & & & & & $*$ & & $*$ & 3 \\
\hline 45 & Ludwigla glandulosa & Onagraceae & & & & & & & $*$ & & 1 \\
\hline 46 & Marsilea crenata & Marsileaceae & & & & & & & $*$ & & 1 \\
\hline 47 & Mimosa pudica var. unijuja & Fabaceae & & & $*$ & & & & & & 1 \\
\hline 48 & Monochloa vaginalis & Pontederiaceae & $*$ & & & $*$ & $*$ & & $*$ & & 4 \\
\hline 49 & Ottochloa nodosa & Graminae & & & & & $*$ & & & & 1 \\
\hline 50 & $\begin{array}{l}\text { Panicum dichotomiflorum } \\
\text { Michx. }\end{array}$ & Graminae & & & & & & & & $*$ & 1 \\
\hline 51 & $\begin{array}{l}\text { Paspalum commersonii sin. } \\
\text { Paspalum scorobiculatum } \mathrm{L} .\end{array}$ & Graminae & $*$ & & & & $*$ & $*$ & & & 3 \\
\hline 52 & Paspalum conjugatum Berg. & Graminae & & & & & $*$ & & & & 1 \\
\hline 53 & Phyllanthus niruri $\mathrm{L}$. & Euphorbiaceae & & & $*$ & & & $*$ & & & 2 \\
\hline 54 & Phyllanthus urinaria $\mathrm{L}$. & Euphorbiaceae & & & & & & & & $*$ & 1 \\
\hline 55 & Pistia stratiotes $\mathrm{L}$. & Araceae & & & & $*$ & & & & & 1 \\
\hline 56 & Rhynchosia minima (L.) DC. & Fabaceae & & & & & & & & $*$ & 1 \\
\hline 57 & Salvinia molesta & Salviniaceae & $*$ & & & & & & & & 1 \\
\hline 58 & Sorgum halepense (L.) Pers. & Graminae & & & & & & & & $*$ & 1 \\
\hline 59 & Sphenoclea zeylanica & Sphenocleaceae & & & & & & & $*$ & & 1 \\
\hline & Jumlah Total & & 12 & 10 & 12 & 10 & 9 & 15 & 11 & 10 & $\begin{array}{l}8 \\
9 \\
\end{array}$ \\
\hline
\end{tabular}

Spesies herbaceous merupakan gulma dominan di lahan sawah (Nithya dan Ramamoorthy, 2015). Gulma Cynodon dactylon (L.) Pers., Fimbristylis miliacae dan Monochloa vaginalis merupakan spesies gulma yang dominan. Gulma perennial (tahunan) menyebabkan masalah yang paling serius di lahan sawah (Shibayama, 1991). Umumnya gulma tersebut menghasilkan biji dalam jumlah besar, yang berada dalam tanah dan berfungsi sebagai bank benih pada musim tanam berikutnya. Gulma tahunan tersebut harus dikendalikan pada waktu yang tepat untuk mencegah pengurangan hasil tanaman. Dan harus dikendalikan sebelum gulma berbunga dan berbuah. Hal tersebut untuk mengurangi produksi benih yang akan menjadi bank benih. Dominasi spesies gulma di lahan padi sawah Indonesia yang telah dilaporkan pada beberapa jurnal penelitian dari tahun 2012-2020 disajikan pada Tabel 3. 
Prosiding Seminar Nasional Pembangunan dan Pendidikan Vokasi Pertanian

Politeknik Pembangunan Pertanian Manokwari, 31 Juli 2021

e ISSN : 2774-1982

DOI : https://doi.org/10.47687/snppvp.v2i1.198

Tabel 3. Dominasi spesies gulma di lahan padi sawah Indonesia yang dilaporkan pada beberapa jurnal penelitian dari tahun 2012-2020

\begin{tabular}{|c|c|c|c|c|c|}
\hline No. & Spesies & $\begin{array}{c}\text { Jumlah } \\
\text { pelaporan }\end{array}$ & No. & Spesies & $\begin{array}{c}\text { Jumlah } \\
\text { pelapor } \\
\text { an }\end{array}$ \\
\hline 1 & Cynodon dactylon (L.) Pers. & \multirow{3}{*}{4} & 10 & $\begin{array}{l}\text { Crassocephalum } \\
\text { crepidioides }\end{array}$ & \multirow{9}{*}{2} \\
\hline 2 & Fimbristylis miliacae & & 11 & Cyperus compressus & \\
\hline 3 & Monochloa vaginalis & & 12 & $\begin{array}{l}\text { Echinochloa crus-galli (L.) } \\
\text { Beauv }\end{array}$ & \\
\hline 4 & Ageratum conyzoides $\mathrm{L}$. & \multirow{6}{*}{3} & 13 & $\begin{array}{l}\text { Eclipta alba } \sin . \text { Eclipta } \\
\text { prostrata }(\mathrm{L} .)\end{array}$ & \\
\hline 5 & Cyperus rotundus & & 14 & $\begin{array}{l}\text { Eichhornia crassipes } \\
\text { (Mart.) Solms }\end{array}$ & \\
\hline 6 & $\begin{array}{l}\text { Digitaria adscendens sin. Digitaria } \\
\text { ciliaris (Retz.) Koel }\end{array}$ & & 15 & Euphorbia hirta & \\
\hline 7 & Echinochloa colona & & 16 & Ipomoea aquatica & \\
\hline 8 & Ludwigia octovalvis & & 17 & $\begin{array}{l}\text { Leptochloa chinensis (L.) } \\
\text { Nees }\end{array}$ & \\
\hline 9 & $\begin{array}{l}\text { Paspalum commersonii } \sin . \\
\text { Paspalum scorobiculatum } \mathrm{L} \text {. }\end{array}$ & & 18 & Phyllanthus niruri $\mathrm{L}$. & \\
\hline
\end{tabular}

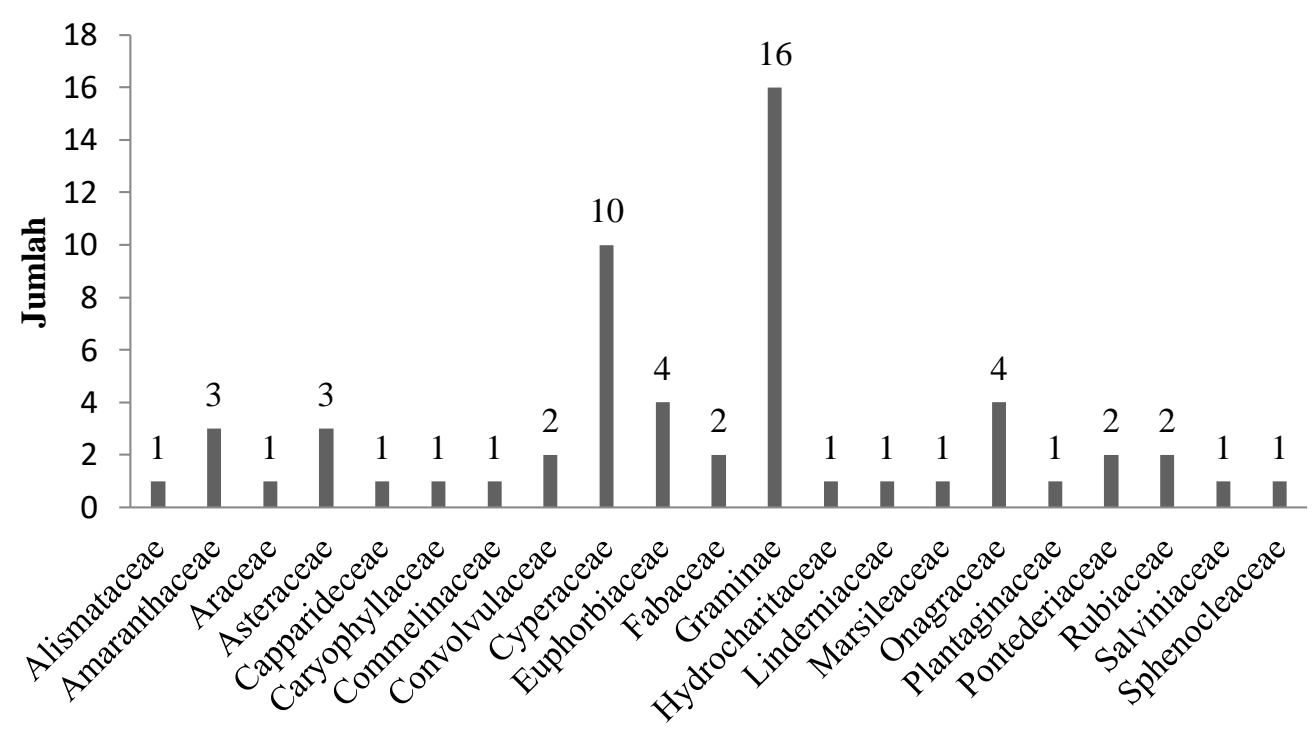

Famili

Gambar 1. Distribusi famili gulma

Pada Gambar 1 terlihat bahwa famili Graminae, Cyperaceae, Euphorbiaceae dan Onagraceae terepresentasikan dengan baik oleh data flora gulma. Famili gulma monokotil mendominasi yaitu famili Graminae dan Cyperaceae, masing-masing direpresentasikan oleh 16 dan 10 spesies. Sebagian besar dari spesies dikotil umumnya kurang berkompetisi dengan tanaman utama pada saat musim tanam (Mendhe, 2020). Mayoritas anggota dari 
Prosiding Seminar Nasional Pembangunan dan Pendidikan Vokasi Pertanian

Politeknik Pembangunan Pertanian Manokwari, 31 Juli 2021

e ISSN : 2774-1982

DOI : https://doi.org/10.47687/snppvp.v2i1.198

famili Graminae dan Cyperaceae berkompetisi dengan padi dan bertanggung jawab atas menurunnya hasil padi.

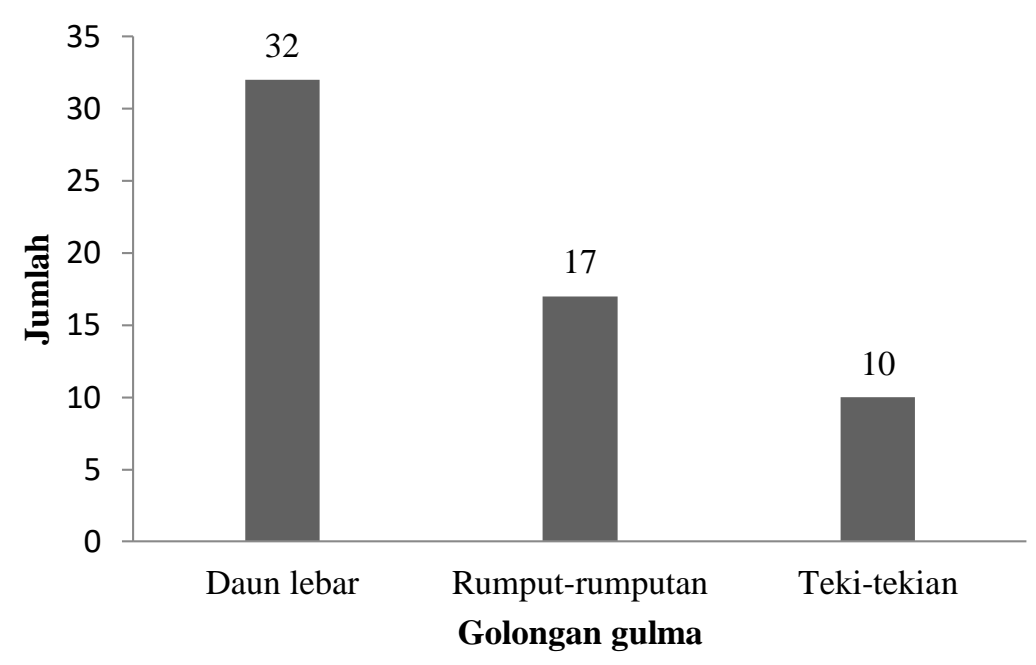

Gambar 2. Distribusi gulma berdasarkan golongan

Atas dasar morfologi dan botani, gulma dikelompokkan menjadi 3 golongan yaitu golongan rumput, golongan teki, dan golongan daun lebar. Pada Gambar 2 terlihat bahwa golongan gulma yang mendominasi yaitu gulma golongan daun lebar (32 spesies), diikuti oleh golongan gulma rumput-rumputan (17 spesies) dan golongan gulma teki-tekian (10 spesies). Golongan gulma daun lebar biasanya tumbuh pada akhir musim tanam, dan kompetisi terhadap tanaman utama yang terjadi yaitu kompetisi cahaya (Perianto et al., 2016). Gulma juga bertanggung jawab tidak langsung pada peningkatan biaya produksi dan berpengaruh langsung pada pertumbuhan dan hasil padi.

\section{KESIMPULAN DAN SARAN}

Komposisi vegetasi dan keragaman gulma pada delapan lahan sawah yang berbeda di Indonesia telah dikaji dari bulan Desember 2012 hingga Agustus 2020. Dari hasil penelusuran pustaka didapatkan 59 spesies gulma di lahan padi sawah. Spesies-spesies ini terdistribusikan di 42 genus dan 21 famili. Gulma Cynodon dactylon (L.) Pers., Fimbristylis miliacae dan Monochloa vaginalis merupakan spesies yang dominan. Famili gulma monokotil mendominasi yaitu famili Graminae dan famili Cyperaceae, masingmasing direpresentasikan oleh 16 dan 10 spesies. golongan gulma yang mendominasi yaitu gulma golongan daun lebar (32 spesies), diikuti oleh golongan gulma rumputrumputan (17 spesies) dan golongan gulma teki-tekian (10 spesies). Untuk saran 
Prosiding Seminar Nasional Pembangunan dan Pendidikan Vokasi Pertanian

Politeknik Pembangunan Pertanian Manokwari, 31 Juli 2021

e ISSN : 2774-1982

DOI : https://doi.org/10.47687/snppvp.v2i1.198

penelitian/kajian selanjutnya dapat diarahkan untuk mempelajari hubungan antara keragaman gulma dengan produktivitas tanaman padi. Adanya paradigma baru di ilmu gulma yaitu semakin tinggi keanekaragaman spesies gulma, maka semakin tinggi produktivitas tanaman tersebut. Paradigma tersebut sudah seharusnya diperkuat dengan penelitian-penelitian di bidang ilmu gulma yang mengkaji tentang hal tersebut.

\section{DAFTAR PUSTAKA}

Bastiaans, L., Kropff, M. J., Goudriaan, J., \& Van Laar, H. H. (2000). Design of weed management systems with a reduced reliance on herbicides poses new challenges and prerequisites for modeling crop-weed interactions. Field Crops Research, 67(2), 161-179. https://doi.org/10.1016/S0378-4290(00)00091-5.

BPS. (2020). BPS: 270,20 juta Penduduk Indonesia Hasil SP2020. https://www.bps.go.id/news/2021/01/21/405/bps--270-20-juta-pendudukindonesia-hasil-sp2020.html.

BPS. (2021). Luas panen padi pada tahun 2020 mengalami penurunan dibandingkan tahun 2019 sebesar 0,19 persen dan produksi padi pada tahun 2020 mengalami kenaikan dibandingkan tahun 2019 sebesar 0,08 persen. 2021-03-01. https://www.bps.go.id/pressrelease/2021/03/01/1855/luas-panen-padi-padatahun-2020-mengalami-penurunan-dibandingkan-tahun-2019-sebesar-0-19persen-dan-produksi-padi-pada-tahun-2020-mengalami-kenaikan-dibandingkantahun-2019-sebesar-0-08-persen.html.

Farmanta, Y. \& Rosmanah, S. (2016). Identifikasi dan dominansi gulma pada pertanaman padi sawahdi kabupaten rejang lebong provinsi bengkulu. 2005, 536-540.

http://repository.pertanian.go.id/bitstream/handle/123456789/6879/sumberdaya 2.pdf?sequence $=1 \&$ is Allowed $=y$.

Fitri, D. S., Syam, Z., \& Solfiyeni. (2014). Komposisi dan Struktur Gulma pada Fase Vegetatif Padi Sawah ( Oryza sativa L.) di Nagari Singkarak Kabupaten Solok Sumatera Barat. Jurnal Biologi Universitas Andalas, 3(1), 68-72.

Fried, G., Petit, S., Dessaint, F., \& Reboud, X. (2009). Arable weed decline in Northern France: Crop edges as refugia for weed conservation? Biological Conservation, 142(1), 238-243. https://doi.org/10.1016/j.biocon.2008.09.029.

Hyvönen, T. (2007). Can conversion to organic farming restore the species composition of arable weed communities? Biological Conservation, 137(3), 382-390. https://doi.org/10.1016/j.biocon.2007.02.021.

Irwansyah, I., Bhaidawi, B., \& Yusuf N, M. (2017). Pengaruh Pola Tanam Terhadap Pertumbuhan Gulma dan Komponen Produksi Tanaman Padi Sawah (Oryza sativa L.). Jurnal Agrium, 14(2), 9. https://doi.org/10.29103/agrium.v14i2.875.

Kurniadie, D., Irda, M., Umiyati, U., Widayat, D., . S., \& Nasahi, C. (2018). Weeds Diversity of Lowland Rice (Oryza sativa L.) with Different farming System in 
Prosiding Seminar Nasional Pembangunan dan Pendidikan Vokasi Pertanian

Politeknik Pembangunan Pertanian Manokwari, 31 Juli 2021

e ISSN : 2774-1982

DOI : https://doi.org/10.47687/snppvp.v2i1.198

Purwakarta Regency Indonesia. Journal of Agronomy, 18(1), 21-26. https://doi.org/10.3923/ja.2019.21.26.

Mendhe, B.K. (2020). Weed Diversity in Paddy Field in Gondia District of. International Archive of Applied Sciences and Technology, 11(March), 70-74.

Nithya, J. \& Ramamoorthy, D. (2015). Floristic composition and weed diversity in rice fields. Indian Journal of Weed Science, 47(4), 417-421.

Palijama, W., Riry, J., \& Wattimena, A. (2018). Komunitas Gulma Pada Pertanaman Pala (Myristica fragrans H.) Belum Menghasilkan Dan Menghasilkan Di Desa Hutumuri Kota Ambon. Agrologia, 1(2). https://doi.org/10.30598/a.v1i2.289.

Perianto, L.H., Soejono, A.T., \& Astuti, Y.T.M. (2016). Komposisi Gulma pada Lahan Kelapa Sawit (Elaeis guineensis Jacq.) pada Tanaman Belum Menghasilkan dan Tanaman Menghasilkan di KP2 Ungaran. Jurnal Agromast, 1(2), 1-13.

Rosanti, D. (2016). Taksonomi Gulma Padi (Oryza sativa) di Areal Persawahan Jakabaring Palembang. Sainmatika, 13(1), 46-51.

Shibayama, H. (1991). Integrated Management of Paddy Weeds in Japan. 1-13.

Syaifudin, A. \& Nofa, F.A. (2020). Jenis-Jenis Gulma Padi ( Oryza sativa L.) di Lahan Pertanian Desa Terban Kecamatan Warungasem Kabupaten Batang Provinsi Jawa Tengah Types of Rice Weeds ( Oryza sativa L. ) in Agricultural Land in Terban Village, Warungasem District, Batang Regency, Cent. 2(2), 128-136.

Syarifah, S., Apriani, I., \& Amallia, R.H.T. (2018). Identifikasi Gulma Tanaman Padi (Oryza sativa L. var. Ciherang) Sumatara Selatan. Jurnal Biosilampari: Jurnal Biologi, 1(1), 40-44. https://doi.org/10.31540/biosilampari.v1i1.52.

Utami, S. \& Purdyaningrum, L.R. (2012). Struktur Komunitas Gulma Padi (Oryza sativa L.) Sawah Organik dan Sawah Anorganik di Desa Ketapang, Kec. Susukan, Kab. Semarang. Bioma: Berkala Ilmiah Biologi, 14(2), 91. https://doi.org/10.14710/bioma.14.2.91-95.

Widayat, D. \& Purba, C.O. (2015). Produktivitas tanaman dan kehilangan hasil tanaman padi (Oryza sativa L.) kultivar Ciherang pada kombinasi jarak tanam dengan frekuensi penyiangan berbeda. Kultivasi, 14 (1), 17-24. https://doi.org/10.24198/kltv.v14i1.12098. 